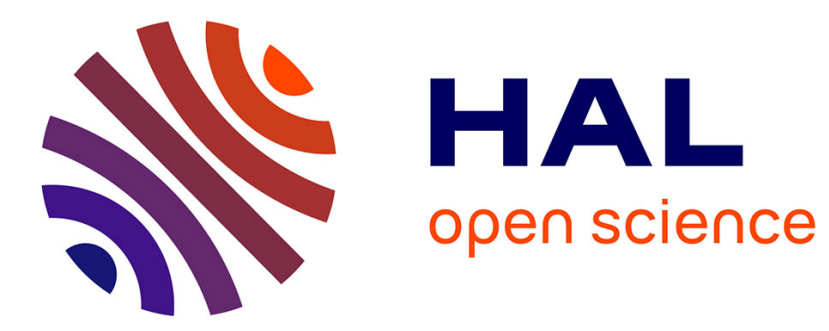

\title{
Theoretical study of structural patterns in CHOP isomers
}

\author{
Raluca Septelean, Petronela Maria Petrar, Nemes Gabriela, Jean Escudié, \\ Ioan Silaghi-Dumitrescu
}

\section{- To cite this version:}

Raluca Septelean, Petronela Maria Petrar, Nemes Gabriela, Jean Escudié, Ioan Silaghi-Dumitrescu. Theoretical study of structural patterns in CHOP isomers. Journal of Molecular Modeling, 2010, 17 (7), pp.1719-1725. 10.1007/s00894-010-0872-8 . hal-00638577

\section{HAL Id: hal-00638577 https://hal.science/hal-00638577}

Submitted on 6 Nov 2011

HAL is a multi-disciplinary open access archive for the deposit and dissemination of scientific research documents, whether they are published or not. The documents may come from teaching and research institutions in France or abroad, or from public or private research centers.
L'archive ouverte pluridisciplinaire HAL, est destinée au dépôt et à la diffusion de documents scientifiques de niveau recherche, publiés ou non, émanant des établissements d'enseignement et de recherche français ou étrangers, des laboratoires publics ou privés. 


\title{
Theoretical study of structural patterns in $\mathrm{CH}_{2} \mathrm{OP}_{2}$ isomers
}

Received: 20.07.2010 / Accepted: 12.09.2010

Raluca Septelean ${ }^{1}$, Petronela M. Petrar ${ }^{1}$, Gabriela Nemes ${ }^{1, \bowtie}$, Jean Escudié ${ }^{2}$, and Ioan SilaghiDumitrescu $^{1}$

${ }^{1}$ Faculty of Chemistry and Chemical Engineering, Babes-Bolyai University, 11, Arany Janos Street, RO-400028, Cluj-Napoca, Romania

${ }^{2}$ Université de Toulouse, UPS, LHFA, 118 route de Narbonne, F-31062 Toulouse; CNRS, LHFA, UMR 5069, F-31062 Toulouse cedex 09, France

${ }^{\square}$ Phone: 40-264-593833; Fax: 0040264590818; Email: sgabi@chem.ubbcluj.ro

\begin{abstract}
DFT calculations have been performed on the derivatives of formula $\mathrm{CH}_{2} \mathrm{OP}_{2}$ to determine their total energy, the relative energy between the isomers and their geometry. Among compounds with a P-C-P linkage, the most stable one is the 2-hydroxy-1,2-diphosphirene II.1, a threemembered heterocycle with a $\mathrm{P}=\mathrm{C}$ unsaturation. The phosphavinylidene(oxo)phosphorane $\mathrm{HP}=\mathrm{C}=\mathrm{P}(\mathrm{O}) \mathrm{H}$ IV.5 (which has the same skeleton as the experimentally obtained Mes $\left.{ }^{*} \mathrm{P}=\mathrm{C}=\mathrm{P}(\mathrm{O}) \mathrm{Mes}^{*}\right)$ lies $36.30 \mathrm{kcal} \mathrm{mol}^{-1}$ above it. The least stable compounds are carbenes; the singlet carbenes are more stable than the triplet ones.
\end{abstract}

Keywords Phosphavinylidene(oxo)phosphorane isomers - DFT calculations $\cdot$ NBO analysis • Heteroallenes 


\section{Introduction}

The geometric and electronic structure of various types of phosphorus compounds is now well known. In the field of doubly-bonded compounds, it is the case of phosphaalkenes $-\mathrm{P}=\mathrm{C}<$ which have been intensely studied [1].

For phosphorus derivatives which possess two cumulated double bonds, such as heteroallenic derivatives $-\mathrm{P}=\mathrm{C}=\mathrm{E}(\mathrm{E}=\mathrm{C}, \mathrm{N}, \mathrm{P}, \mathrm{O})[2]$, ab initio calculations have been reported on the parent 1,3-diphosphaallene $\mathrm{HP}=\mathrm{C}=\mathrm{PH}$, on several $\mathrm{XP}=\mathrm{C}=\mathrm{PX}(\mathrm{X}=\mathrm{H}, \mathrm{F}, \mathrm{Cl})$ models $[3,4]$, on azaphosphaallene $\mathrm{HP}=\mathrm{C}=\mathrm{NH},[3,5]$ and on phosphaketene $\mathrm{HP}=\mathrm{C}=\mathrm{O}[6]$. The results on the geometries, the substituents' effect on the stability of these heteroallenes and their isomers, their configurational stability, their electronic structure and several other molecular properties have been studied and compared to those of phosphaalkenes $-\mathrm{P}=\mathrm{C}<$ and also to carbodiimides $-\mathrm{N}=\mathrm{C}=\mathrm{N}-$.

We have been interested in the synthesis, characterization and reactivity of a new type of diphosphaallenes and have reported the synthesis and characterization of the phosphavinylidene(oxo)phosphorane $\mathrm{Mes} * \mathrm{P}=\mathrm{C}=\mathrm{P}(\mathrm{O}) \mathrm{Mes}^{*} \quad$ (Mes*=2,4,6-tri-tert-butylphenyl), the first diphosphaallene containing both $\lambda^{3} \sigma^{2}$ and $\lambda^{5} \sigma^{3}$ phosphorus atoms [7]. Such system offers potential use as transition metal ligands and elucidation of its electronic structure should provide insight in the nature of heteroallenic compounds, leading to the design of better synthetic routes. The presence of two phosphorus atoms in a molecule with different bonding to carbon or oxygen atoms might induce electronic effects influencing the structural parameters and stability of such derivatives.

This paper reports density functional theory (DFT) calculations on the $\mathrm{HP}=\mathrm{C}=\mathrm{P}(\mathrm{O}) \mathrm{H}$ model and its isomers of the general formula $\mathrm{CH}_{2} \mathrm{OP}_{2}$ in order to determine the most stable systems and thus most likely to be experimentally obtained. The main geometrical parameters of all these derivatives are also reported. Although calculations have been performed on all the possible isomers, we limit our presentation to cyclic and acyclic derivatives with a P-C-P linkage. 


\section{Methods}

Starting structures were built with GaussView 4.1 [8]. Geometries were optimized using the Gaussian 09 software package [9], at the B3LYP/6-311++G(d,p) level of theory using the default convergence criteria. Single-point calculations were also performed using high-correlation (CCSD/SDQ/6-31G*) and Moeller-Plesset (MP4/6-31G*) methods in order to see if the results are in agreement with the DFT data. Vibrational analyses confirmed that all geometries shown here represent true minima.

\section{Results and discussion}

Depending on the skeleton, the results have been grouped in different series: cyclic series with four-membered rings (I), two series containing three-membered rings (a PPC cycle (II) and a PCO cycle (III)), and a non-cyclic series with a PCP skeleton (IV) (Scheme 1). We have long been interested in the field of heteroallenes of the type $\mathrm{P}=\mathrm{C}=\mathrm{E}$, , particularly 1,3diphosphaallenic compounds [2,7]; thus, the current discussion will be focused on derivatives containing the P-C-P unit. All of the other possible isomers were also found, but this discussion will only refer to cyclic or non-cyclic structures built starting from the above mentioned moiety. Where several conformers were identified, only the most stable of them is reported. The isomers studied include doubly- or triply-bonded derivatives as well as carbenes.

$<$ Scheme 1 $>$

Fig. 1 presents the relative energies of all of the investigated structures optimized with DFT method. The optimized structures of the isomers are presented in Table 1 together with relevant geometrical data.

$<$ Figure $1>$

$<$ Table 1 $>$ 
The most stable of all the possible isomers with a P-C-P linkage was found to be the threemembered heterocycle 2-hydroxy-1,2-diphosphirene II.1 (Table 1). Thus, energies of all the isomers discussed in this paper are given relative to its total energy. Fig. 1 is instructive from an experimental point of view, as it illustrates 7 structures within $\sim 10 \mathrm{kcal} \mathrm{mol}^{-1}$ of the reference energy, suggesting a wide variety of isomers may be accessible experimentally and very close in energy to each other, which offers promise but also warns of difficulties in isolating pure compounds in good yields. However, substitution with bulky groups at both P1 and P2 should have an important effect on the stabilization of these derivatives and should thus allow a better control of the synthetic route towards the desired target.

In the four-membered ring series, the most stable isomer is the $2 H-1,2,4$-oxadiphosphete (I.1) with a relative energy of $4.74 \mathrm{kcal} \mathrm{mol}^{-1}$ in relation to II.1. Three-membered heterocycles with a PCO ring skeleton are calculated to be less stable than the ones with a PPC ring (for example $29.33 \mathrm{kcal} \mathrm{mol}^{-1}$ for III.1).

In the case of open-chain structures, the most stable compounds are IV.1 and IV.2 $(Z, E$ isomers of $\mathrm{HP}=\mathrm{CH}-\mathrm{P}=\mathrm{O}$ ), followed by the phosphaacetylenic derivatives IV.3 and IV.4 (7.83 and 15.09 kcal mol ${ }^{-1}$, respectively) and the phosphavinylidene(oxo)phosphorane IV.5 (36.30 $\left.\mathrm{kcal} \mathrm{mol}^{-1}\right)$. For all the series investigated, the carbenoid structures are the most unstable isomers (generally 45 to $84 \mathrm{kcal} \mathrm{mol}^{-1}$ higher in energy than the three-membered ring derivative II.1).

Singlet structures were calculated to be more stable than the triplet ones. For example I.4 was calculated to be $12.98 \mathrm{kcal} \mathrm{mol}^{-1}$ more stable than $\mathbf{I . 5}$ (with the hydrogen atoms in a trans position relative to the four-membered ring). For the cis-structures (investigated, but not shown in Table 1, the difference is somewhat smaller (around $7 \mathrm{kcal} \mathrm{mol}^{-1}$ )).

A model of the bis(supermesityl)phosphavinylidene(oxo)phosphorane Mes ${ }^{*} \mathrm{P}=\mathrm{C}=\mathrm{P}(\mathrm{O}) \mathrm{Mes}$ * (Mes* $=2,4,6$-tri-tert-butylphenyl) [7], shown experimentally to be stable at room temperature, is found among those shown in Table $4-\mathrm{HP}=\mathrm{C}=\mathrm{P}(\mathrm{O}) \mathrm{H}$ IV.5,- and is not among the most stable $\mathrm{CH}_{2} \mathrm{OP}_{2}$ derivatives. In principle, there are several possibilities whereby Mes ${ }^{*} \mathrm{P}=\mathrm{C}=\mathrm{P}(\mathrm{O}) \mathrm{Mes}$ * could rearrange to structures predicted more stable in Table 1: by a cyclization of the $\mathrm{C}=\mathrm{P}=\mathrm{O}$ unit (to lead to the structures of the type III.1), by a migration of the organic group from a phosphorus to the adjacent carbon atom (to form analogues of IV.1 or IV.2), or by migration of the substituent to the second phosphorus or the oxygen atoms (to form phosphaacetylenic 
compounds like IV.3 and IV.4). All the resulting structures are calculated to be more stable in the case of the model compounds. The stability of the diphosphaallene Mes* $\mathrm{P}=\mathrm{C}=\mathrm{P}(\mathrm{O}) \mathrm{Mes} *$ is probably due to steric reasons. For instance, in a structure of the type IV.1 and IV.2, the presence of two extremely bulky supermesityl groups on adjacent atoms ( $\mathrm{P}$ and $\mathrm{C}$ ) is unlikely, as well as a very hindering group on the central carbon atom. The fact that phosphaacetylenic derivatives were calculated to be among the most stable structures is not surprising since phosphaalkynes $\mathrm{RC} \equiv \mathrm{P}$ are well known [10], and their stabilization is possible even in the absence of a bulky group such as a supermesityl.

Ab initio calculations (HF/4-31G and HF/DZP-11s7p2d/6s $4 p 2 d$ for the $\mathrm{P}$ atom) performed on models with the $\mathrm{CH}_{2} \mathrm{P}_{2}$ formula placed a diphosphirene structure (a three-membered ring with a $\mathrm{P}=\mathrm{P}$ double bond and a $\mathrm{CH}_{2}$ group) as the most stable of the series [4]. The authors conclude that stable non-cyclic structures are the ones containing the maximum number of $\mathrm{C}-\mathrm{H}$ bonds, while $\mathrm{P}-\mathrm{H}$ bonds have the tendency to destabilize the molecules. The hybridization of the carbon atom also influences the models' stability: the presence of an $s p^{3}$ carbon atom leads to a more stable structure, while an $s p^{2}$ one has the opposite effect. However, this pattern does not apply in our case, most likely due to the presence of the oxygen atom.

Calculated $\mathrm{P}=\mathrm{C}, \mathrm{P}=\mathrm{P}, \mathrm{P}=\mathrm{O}$ and $\mathrm{P} \equiv \mathrm{C}$ distances are in the normal range for multiple-bonded phosphorus atoms. The $\mathrm{P} \equiv \mathrm{C}$ bond lengths in IV.3 and IV.4 (1.554 and $1.547 \AA$ ) are slightly longer than that measured by X-ray for $\mathrm{Mes}^{*} \mathrm{C} \equiv \mathrm{P}(1.516(13) \AA[11])$, but in agreement with values reported in the gas phase [12].

For the diphosphaallene $\mathrm{HP}=\mathrm{C}=\mathrm{P}(\mathrm{O}) \mathrm{H}$ IV.5, the calculated $\mathrm{P}-\mathrm{C}-\mathrm{P}$ angle $\left(170.1^{\circ}\right)$ and the $\mathrm{P}=\mathrm{C}$ bond lengths (1.638 $\AA$ for the trivalent phosphorus atom and $1.621 \AA$ for the pentavalent one) are in agreement with experimental data [12]. A comparison with the geometrical parameters of Mes $* \mathrm{P}=\mathrm{C}=\mathrm{P}(\mathrm{O}) \mathrm{Mes}^{*}$ is not possible, since its X-ray structure has not been determined, but they are similar to those reported for other heteroallenes, for example Mes ${ }^{*} \mathrm{P}=\mathrm{C}=\mathrm{PMes}^{*}$ measured through X-ray diffraction $\left(172.52^{\circ}, 1.630\right.$ and $1.634 \AA$, see Table 2) [13]. In all heteroallenic structures, the $\mathrm{E}=\mathrm{C}=\mathrm{E}^{\prime}$ bond angle $(\mathrm{E}, \mathrm{E}$ ': $\mathrm{Si}, \mathrm{Ge}, \mathrm{P}, \mathrm{As})$ is never the ideal $180^{\circ}$ but slightly more acute [2]. This is also obtained for the model compound IV.5 (for which the value of the P-C-P angle is $170.1^{\circ}$ ), which would imply that the lack of linearity is not the effect of packing in the solid state, but a property inherent to the electronic structure of the diphosphaallene. To verify this further, we examined at the same level of theory model compounds including the allene 
$\mathrm{H}_{2} \mathrm{C}=\mathrm{C}=\mathrm{CH}_{2}$ and its analogues obtained by replacing one or two terminal atoms with $\mathrm{N}$ or $\mathrm{P}$. The geometry was linear, as expected, in the sole case of the allene. The replacement of only one terminal carbon atom with either $\mathrm{N}$ or $\mathrm{P}$ leads to a $5^{\circ}$ deviation, while in the case of 1,3diazaallene and 1,3-diphosphaallene $-\mathrm{P}=\mathrm{C}=\mathrm{P}-$, the angle is around $170^{\circ}$. The NBO analysis shows in the case of the 1-aza- and 1-phosphaallenes $(-\mathrm{E}=\mathrm{C}=\mathrm{C}<, \mathrm{E}=\mathrm{N}, \mathrm{P})$ interactions between the lone pairs on the heteroatom and vacant antibonding orbitals (of both $\sigma$ and $\pi$ symmetry) localized on the $\mathrm{C}=\mathrm{C}$. In the case of the diphosphaallenes, charge transfers from a lone pair of one phosphorus atom to a $\sigma$ antibonding orbital localized on the C-P bond involving the other phosphorus are present, these interactions forcing the P-C-P angle to narrow. This type of interaction is also present for the discussed derivative IV.5 between the lone pair of the $\lambda^{3} \sigma^{2} \mathrm{P}$ and an antibonding orbital of $\sigma$ symmetry on $\lambda^{5} \sigma^{3} \mathrm{P}-\mathrm{C}$; the orbitals involved are represented in Fig. 2.

$<$ Figure 2 $>$

$<$ Table 2>

The data of Table 2 show that the P-C-P angle is as expected highly dependent on the nature of the substituents on the phosphorus atom and of its hybridization [13-18]. A very strained angle of $115.05^{\circ}$ has been reported for $i-\mathrm{Pr}_{2} \mathrm{NP}=\mathrm{C}=\mathrm{PPh}_{2} \mathrm{~N} i-\mathrm{Pr}_{2}$ [16], a derivative containing dicoordinated trivalent and tetracoordinated pentavalent phosphorus atoms in the PCP backbone. Thus, it can be seen that for $\lambda^{5} \sigma^{3}-\mathrm{P}=\mathrm{C}=\mathrm{P}-\lambda^{3} \sigma^{2}$ and $\lambda^{3} \sigma^{2}-\mathrm{P}=\mathrm{C}=\mathrm{P}-\lambda^{3} \sigma^{2}$ derivatives, the experimental data are in fair agreement with the structural parameters calculated herein.

The Mulliken charges calculated for IV.5 are given in Fig. 3.

$<$ Figure $3>$

The difference between the calculated charges on the two phosphorus atoms are in agreement with the experimental data: the $\mathrm{P}=\mathrm{C}$ double bond containing the $\lambda^{5} \sigma^{3}$ phosphorus atom is computed to be more polarized than the one with the $\lambda^{3} \sigma^{2}$ phosphorus atom and is indeed more reactive towards even weakly acidic derivatives. This has been experimentally observed by the preferential addition of water to the $\lambda^{5} \sigma^{3} \mathrm{P}=\mathrm{C}$ double bond in Mes $* \mathrm{P}=\mathrm{C}=\mathrm{P}(\mathrm{O}) \mathrm{Mes}^{*}$ [7]. 
The model compound Mes $* \mathrm{P}=\mathrm{C}=\mathrm{P}(\mathrm{O}) \mathrm{Mes}^{*}$ has also been investigated at the $\mathrm{B} 3 \mathrm{LYP} / 6$ $311++\mathrm{G}(\mathrm{d}, \mathrm{p})$ level of the theory, and the geometry parameters are similar to those obtained for $\mathrm{HP}=\mathrm{C}=\mathrm{P}(\mathrm{O}) \mathrm{H}: 1.635 \AA$ for the $\mathrm{P} 1-\mathrm{C}$ bond, $1.620 \AA$ for $\mathrm{P} 2-\mathrm{C}$ and $1.497 \AA$ for the $\mathrm{P}-\mathrm{O}$ distance, and also in agreement with the experimental values shown for the compounds in Table 2 . The energy difference between $\mathrm{Mes}^{*} \mathrm{P}=\mathrm{C}=\mathrm{P}(\mathrm{O}) \mathrm{Mes}^{*}$ and the Mes*-substituted derivative II.1 decreases to $23.11 \mathrm{kcal} \mathrm{mol}^{-1}$ when compared to the hydrogen-substituted analogues $(36.30 \mathrm{kcal}$ $\mathrm{mol}^{-1}$ ). This could be an argument in the favor of the stabilization offered by steric hindrance in such compounds, which was observed experimentally, since Mes*P=C=P(O)Mes* has been obtained and isolated.

Single point calculations have also been performed for all isomers by higher correlation methods $\operatorname{CCSD}(\mathrm{SDQ})$ and MP4 with the $6-311++\mathrm{G}(\mathrm{d}, \mathrm{p})$ basis set, in order to compare them with DFT calculations. The results maintain the relative energy ordering, with the exception of structures IV, for which IV.3 is found to be the minimum of the series. The structure of interest IV.5 is higher in energy than the II.1 model compound by $39.08 \mathrm{kcal} \mathrm{mol}^{-1}(\mathrm{CCSD} / 6-311++\mathrm{G}(\mathrm{d}, \mathrm{p}))$ and $37.90 \mathrm{kcal} \mathrm{mol}^{-1}$ (MP4(SDQ)/6-311++G(d,p)), respectively. The calculated energies are given in Table 3.

$<$ Table 3>

For the acyclic series, the Wiberg bond order [19] has also been calculated at the B3LYP/6$311++\mathrm{G}(\mathrm{d}, \mathrm{p})$ level, and a NBO [20] analysis was performed. The results are given in Table 4. For the model compound $\mathrm{HP}=\mathrm{C}=\mathrm{P}(\mathrm{O}) \mathrm{H}$ IV.5, the calculated bond orders are 1.89 for the $\lambda^{3} \sigma^{2} \mathrm{P}$ $\mathrm{C}$ bond and a lower order, of 1.57, for the $\lambda^{5} \sigma^{3} \mathrm{P}-\mathrm{C}$ one. As expected, for the triplet state IV.7, the bond orders are much smaller than for the singlet state IV.6.

$<$ Table 4>

The lower bond order is explained by the NBO analysis which shows that second-order interactions occur between the lone pairs on the $\mathrm{O}$ atom and the antibonding orbitals of both $\sigma$ (represented in Fig. 2) and $\pi$ symmetry localized on $\lambda^{5} \sigma^{3}$ P-C bond (Fig. 4) leading to a population of the latter and thus the lowering of the bond order.

$<$ Figure $4>$ 


\section{Summary}

Although the phosphavinylidene(oxo)phosphorane $\mathrm{HP}=\mathrm{C}=\mathrm{P}(\mathrm{O}) \mathrm{H}$ is calculated to be one of the least stable isomers of the $\mathrm{CH}_{2} \mathrm{OP}_{2}$ formula (if we exclude carbenes and phosphinidenes), its corresponding bis(supermesityl) substituted derivative $\mathrm{Mes}^{*} \mathrm{P}=\mathrm{C}=\mathrm{P}(\mathrm{O}) \mathrm{Mes} *$ has been experimentally obtained, while the other possible isomers were not stabilized until now. It should be possible to obtain three-membered ring heterocycles with $\mathrm{P}=\mathrm{C}$ or $\mathrm{P}=\mathrm{P}$ double bonds and acyclic compounds with a $\mathrm{P}=\mathrm{C}-\mathrm{P}$ or a $\mathrm{P} \equiv \mathrm{C}$ unit, which are calculated to be more stable, pending a judicious choice of substituents.

\section{Acknowledgments}

This work was supported by Consiliul National al Cercetarii Stiintifice din Invatamantul Superior (CNCSIS), project number PNII - ID_PCCE_140/2008. J.E. is thankful for partial financial support from European Cooperation in Science and Technology (EU COST) Action number CM0802 PhoSciNet. Radu Silaghi-Dumitrescu (Babes-Bolyai University) is thanked for useful discussions. 


\section{References}

1. For

reviews

see

a) Appel R, Knoll F, Ruppert I (1981) Phospha-alkenes and Phospha-alkynes, Genesis and

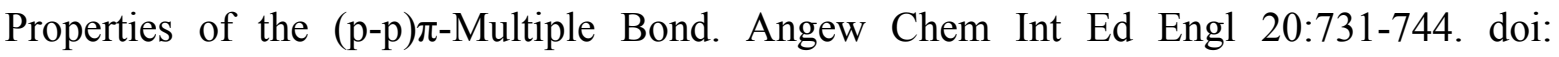
10.1002/anie.198107311; Phospha-alkene und Phospha-alkine, Genese und Charakteristika

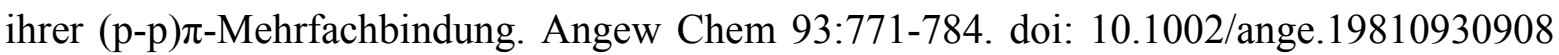
b) Fluck E (1980) Compounds of phosphorus with coordination number 2. In: Grayson M, Griffith EJ (eds) Topics in Phosphorus Chemistry, vol 10. J Wiley, New York, pp 193-284

c) Kroto HW (1982) Tilden Lecture. Semistable molecules in the laboratory and in space. Chem Soc Rev 11:435-491. doi 0.1039/CS9821100435

2. For reviews see a) Escudié J, Ranaivonjatovo H, Rigon L (2000) Heavy Allenes and Cumulenes $\mathrm{E}=\mathrm{C}=\mathrm{E}$ ' and $\mathrm{E}=\mathrm{C}=\mathrm{C}=\mathrm{E}^{\prime}\left(\mathrm{E}=\mathrm{P}, \mathrm{As}, \mathrm{Si}, \mathrm{Ge}, \mathrm{Sn} ; \mathrm{E}^{\prime}=\mathrm{C}, \mathrm{N}, \mathrm{P}, \mathrm{As}, \mathrm{O}, \mathrm{S}\right)$. Chem Rev 100:3639-3696. doi:

$10.1021 / \mathrm{cr} 990013 \mathrm{z}$

b) Escudié J, Ranaivonjatovo H, Bouslikhane M, El Harouch Y, Baiget L, Cretiu Nemes G (2004) Phosphasila-, phosphagerma-, and phosphaarsaallenes $-\mathrm{P}=\mathrm{C}=\mathrm{E}(\mathrm{E}=\mathrm{Si}, \mathrm{Ge}, \mathrm{As})$ and arsa- and diarsaallenes $-\mathrm{As}=\mathrm{C}^{\prime}=\mathrm{E}^{\prime} \quad\left(\mathrm{E}^{\prime}=\mathrm{C}\right.$, As). Russ Chem Bull 53:1020-1033. doi: 10.1023/B:RUCB.0000041301.62839.ba

c) Escudié J, Ranaivonjatovo H (2007) Group 14 and 15 Heteroallenes $\mathrm{E}=\mathrm{C}=\mathrm{C}$ and $\mathrm{E}=\mathrm{C}=\mathrm{E}^{\text {‘ }}$. Organometallics 26:1542-1559. doi: 10.1021/om0610086

3. Nguyen MT, Hegarty AF (1985) Structures and properties of carboimidophosphene (HP=C$\mathrm{NH})$ and carbodiphosphene $(\mathrm{HP}=\mathrm{C}=\mathrm{PH})$. An ab initio study. J Chem Soc, Perkin Trans 2:2005-2012. doi: 10.1039/P29850002005

4. Fitzpatrick NJ, Brougham DF, Groarke PJ, Nguyen MT (1994) Effect of Fluorine and Chlorine Substituents on Stabilities of Diphosphaallene, Diphosphirene, and Phosphanylphosphaalkyne Isomers $\left(\mathrm{XX}^{\prime} \mathrm{CP}_{2}\right.$ Species with $\mathrm{X}, \mathrm{X}^{\prime}=\mathrm{H}, \mathrm{F}$, and $\left.\mathrm{Cl}\right)$. Chem Ber 127:969-978. doi: 10.1002/cber.199412706022.

5. Yoshifuji M, Niitsu T, Toyota K, Inamoto N, Hirotsu K, Odagaki Y, Higuchi T, Nagase S (1988) X-ray structure of a sterically protected 1-aza-3-phosphaallene. Polyhedron 7:22132216. doi:10.1016/S0277-5387(00)81807-0

6. Nguyen MT, Hegarty AF, McGinn MA, Ruelle F (1985) Structure and properties of phosphaketene $(\mathrm{H}-\mathrm{P}=\mathrm{C}=\mathrm{O})$ : phosphorus versus oxygen protonation? J Chem Soc, Perkin Trans 2:1991-1997. doi: 10.1039/P29850001991 
7. Septelean R, Ranaivonjatovo H, Nemes G, Escudié J, Silaghi-Dumitrescu I, Gornitzka H, Silaghi-Dumitrescu L, Massou S (2006) Phosphavinylidene(oxo)phosphorane Mes* $\mathrm{P}(\mathrm{O})=\mathrm{C}=\mathrm{PMes} *$ : A Diphosphaallene Featuring $\lambda^{5} \sigma^{3}$ - and $\lambda^{3} \sigma^{2}$-Phosphorus Atoms. Eur J Inorg Chem 2006:4237-4241. doi: 10.1002/ejic.200690043

8. Dennington II R, Keith T, Millam J, Eppinnett K, Hovell WL, Gilliland R (2003) GaussView, Version 4.1. Semichem Inc, Shawnee Mission, KS

9. Frisch MJ, Trucks GW, Schlegel HB, Scuseria GE, Robb MA, Cheeseman JR, Scalmani G, Barone V, Mennucci B, Petersson GA, Nakatsuji H, Caricato M, Li X, Hratchian HP, Izmaylov AF, Bloino J, Zheng G, Sonnenberg JL, Hada M, Ehara M, Toyota K, Fukuda R, Hasegawa J, Ishida M, Nakajima T, Honda Y, Kitao O, Nakai H, Vreven T, Montgomery JA Jr, Peralta JE, Ogliaro F, Bearpark M, Heyd JJ, Brothers E, Kudin KN, Staroverov VN, Kobayashi R, Normand J, Raghavachari K, Rendell A, Burant JC, Iyengar SS, Tomasi J, Cossi M, Rega N, Millam JM, Klene M, Knox JE, Cross JB, Bakken V, Adamo C, Jaramillo J, Gomperts R, Stratmann RE, Yazyev O, Austin AJ, Cammi R, Pomelli C, Ochterski JW, Martin RL, Morokuma K, Zakrzewski VG, Voth GA, Salvador P, Dannenberg JJ, Dapprich S, Daniels AD, Farkas Ö, Foresman JB, Ortiz JV, Cioslowski J, Fox DJ (2009) Gaussian 09, Revision A.1. Gaussian Inc, Wallingford CT

10. a) Bergsträsser U (2005) Triple-bonded Heteroatom Derivatives Other than Nitriles with Another Heteroatom Attached to the sp Carbon Atom in Katritzky AR, Taylor RJK (eds) Comprehensive Organic Functional Group Transformations II, vol 5. Elsevier, Oxford, pp 1099-1111

b) Regitz M, Binger P (1988) Phosphaalkynes - Syntheses, reactions, coordination behavior. Angew Chem Int Ed 27:1484-1508. doi 10.1002/anie.198814841 c) Markovski LN, Romanenko VD (1989) Phosphaalkynes and phosphaalkenes. Tetrahedron 45:6019-6090. doi 10.1016/S0040-4020(01)85121-8

11. Arif AM, Barron AR, Cowley AH, Hall SW (1988) Reaction of the phospha-alkyne ArCP $\left(\mathrm{Ar}=2,4,6-t-\mathrm{Bu}_{3} \mathrm{C}_{6} \mathrm{H}_{2}\right)$ with nucleophiles: a new approach to 1,3-diphosphabutadiene synthesis. J Chem Soc Chem Commun 171-172. doi 10.1039/C39880000171

12. Lide DR (ed) (2009-2010) CRC Handbook of Chemistry and Physics, 90 ${ }^{\text {th }}$ edn. CRC Press, Boca Raton, Florida

13. Karsch HH, Reisacher HU, Muller G (1984) Molecular Structure of a 1,3-Diphosphaallene: $\left(2,4,6-t-\mathrm{Bu}_{3} \mathrm{C}_{6} \mathrm{H}_{2}\right) \mathrm{P}=\mathrm{C}=\mathrm{P}\left(2,4,6-t-\mathrm{Bu}_{3} \mathrm{C}_{6} \mathrm{H}_{2}\right)$, a Phosphorus Analogue of Carbon Disulfide. Angew Chem Int Ed Eng1 23:618-619. doi 10.1002/anie.198406181 
14. Schubert U, Kappenstein C, Milewski-Mahrla B, Schmidbaur H (1981) Molekül- und Kristallstrukturen zweier Carbodiphosphorane mit PCP-Bindungswinkeln nahe $120^{\circ}$. Chem Ber 114:3070-3078. doi:10.1002/cber.19811140914

15. Hardy GE, Kaska WC, Chandra BP, Zink JI (1981) Triboluminescence-structure relationships in polymorphs of hexaphenylcarbodiphosphorane and anthranilic acid, molecular crystals, and salts. J Am Chem Soc 103:1074-1079. doi: 10.1021/ja00395a014

16. Martin D, Gornitzka H, Baceiredo A, Bertrand G (2005) C-Phosphoniophosphaalkenes as Precursors of $1 \sigma^{4}, 3 \sigma^{2}$-Diphosphaallenes: Scope and Limitations. Eur $\mathrm{J}$ Inorg Chem 2005:2619-2624. doi 10.1002/ejic.200500014

17. Shevchenko IV, Mikolenko RN, Lork E, Röschenthaler G-V (2001) Interaction of Some Methylenediphosphanes with Hexafluoroacetone and Hexafluorothioacetone Dimer. Eur J Inorg Chem 2001:2377-2383. doi: 10.1002/1099-0682(200109)2001:9<2377::AIDEJIC2377>3.0.CO;2-3

18. Kato T, Gornitzka H, Baceiredo A, Bertrand G (2000) Synthesis, Structure, and Reactivity of a $1 \sigma^{4}, 3 \sigma^{2}$-Diphosphaallene. Angew Chem Int Ed Engl 39:3319-3321. doi: 10.1002/15213773(20000915)39:18<3319::AID-ANIE3319>3.0.CO;2-M

19. Wiberg KB (1968) Application of the pople-santry-segal CNDO method to the cyclopropylcarbinyl and cyclobutyl cation and to bicyclobutane. Tetrahedron 24:1083-1096. doi: 10.1016/0040-4020(68)88057-3

20. Glendening ED, Badenhoop JK, Reed AE, Carpenter JE, Bohmann JA, Morales CM, Weinhold F (2001) NBO 5.0. Theoretical Chemistry Institute, University of Wisconsin. 


\section{Tables}

Table 1 Selected bond lengths $(\AA)$ for $\mathrm{CH}_{2} \mathrm{OP}_{2}$ isomers

\begin{tabular}{|c|c|c|c|c|c|}
\hline I & 1 & 2 & 3 & 4 & 5 \\
\hline $\begin{array}{l}\mathrm{P} 1-\mathrm{C} \\
\mathrm{P} 1-\mathrm{O} \\
\mathrm{P} 2-\mathrm{C} \\
\mathrm{P} 2-\mathrm{O}\end{array}$ & $\begin{array}{c}2 \mathrm{O}-1,2,4- \\
\text { oxadiphosphete } \\
1.681 \\
1.699 \\
1.821 \\
1.725\end{array}$ & $\begin{array}{c}\text { oxadiphosphetane } \\
\text {-2,4-diyl diradical, } \\
\text { triplet } \\
1.882 \\
1.710 \\
1.882 \\
1.710\end{array}$ & $\begin{array}{c}\text { oxadiphospheta } \\
\text { ne-2,4-diyl } \\
\text { diradical, singlet } \\
1.866 \\
1.679 \\
1.866 \\
1.679\end{array}$ & $\begin{array}{c}1,2,4- \\
\text { oxadiphosphetan-3- } \\
\text { ylidene, trans, } \\
\text { singlet } \\
1.755 \\
1.723 \\
1.754 \\
1.723\end{array}$ & $\begin{array}{c}\text { 1,2,4- } \\
\text { oxadiphosphetan- } \\
\text { 3-ylidene, trans, } \\
\text { triplet } \\
1.808 \\
1.728 \\
1.808 \\
1.728\end{array}$ \\
\hline
\end{tabular}

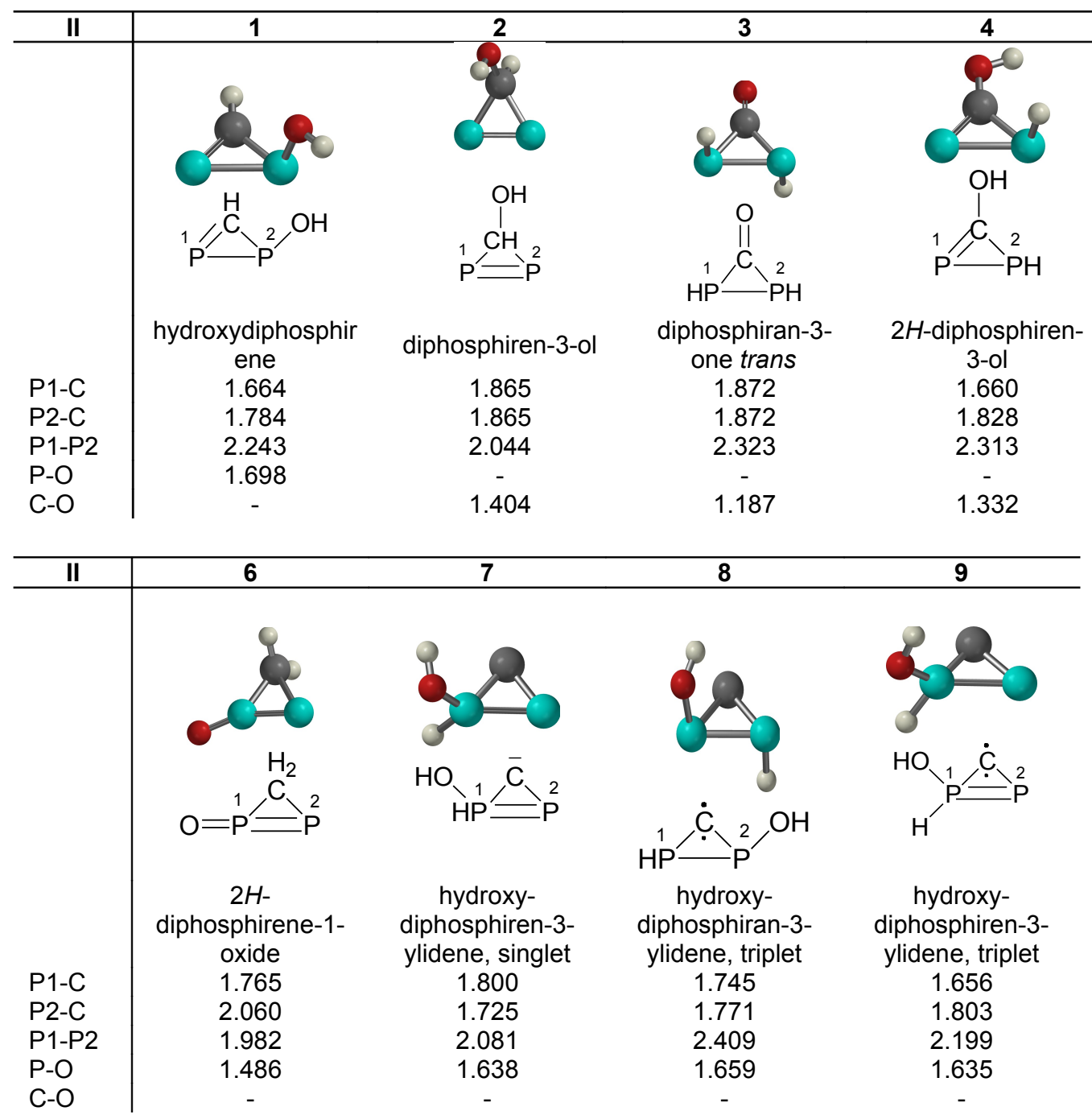




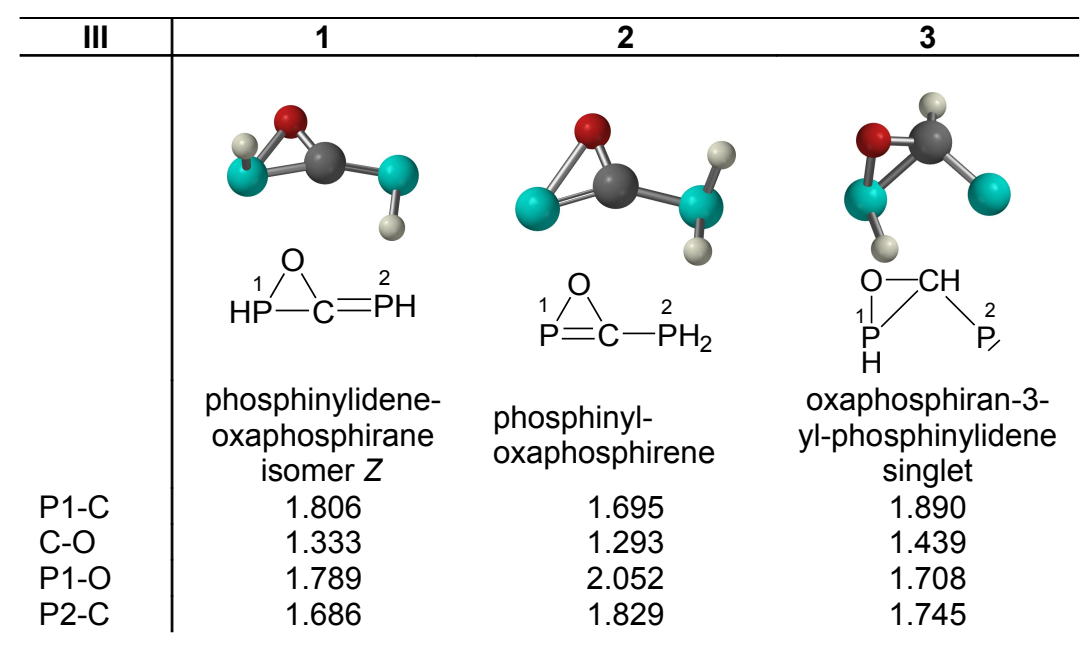

\begin{tabular}{|c|c|c|c|c|c|}
\hline IV & 1 & 2 & 3 & 4 & 5 \\
\hline $\begin{array}{l}\text { P1-C } \\
\text { P2-C } \\
\text { P2-O }\end{array}$ & $\begin{array}{c}\text { exo(Z)phosphinid } \\
\text { enemethyl]phos- } \\
\text { phine } \\
1.682 \\
1.828 \\
1.499\end{array}$ & $\begin{array}{c}\mathrm{H} \\
\mathrm{HP}=\mathrm{C}-\mathrm{P}=\mathrm{O} \\
\text { exo(E)phosphinid } \\
\text { enemethyl]phos- } \\
\text { phine } \\
1.685 \\
1.829 \\
1.500\end{array}$ & $\begin{array}{c}\text { hydroxy- } \\
\text { phosphinylidynem } \\
\text { ethyl)-phosphine } \\
1.554 \\
1.778 \\
1.681\end{array}$ & $\begin{array}{c}1 \\
\mathrm{P} \equiv \mathrm{C}-\mathrm{P}^{2} \\
\text { (phosphinylidynem } \\
\text { ethyl)phosphine } \\
\text { oxide } \\
1.547 \\
1.781 \\
1.491\end{array}$ & $\begin{array}{c}1 \\
\mathrm{HP}=\mathrm{C}=\mathrm{P}^{2} \\
\text { phosphavinylidene } \\
\text { (oxo)phosphorane } \\
1.638 \\
1.621 \\
1.489\end{array}$ \\
\hline $\begin{array}{l}P 1-C \\
P 2-C \\
P 1-O\end{array}$ & $\begin{array}{c}1 \\
\mathrm{H}_{2} \mathrm{P}-\overline{\mathrm{C}}-\mathrm{P}^{-} \\
\text {(phosphinylmethyli } \\
\text { dyne)phosphine } \\
\text { oxide, singlet } \\
1.664 \\
1.657 \\
1.499\end{array}$ & $\begin{array}{c}\mathrm{H}_{2} \mathrm{P}-\dot{\mathrm{C}}-\mathrm{P}^{\prime} \\
\text { phosphinylmethylid } \\
\text { yne)phosphine } \\
\text { oxide, triplet } \\
1.756 \\
1.767 \\
1.520\end{array}$ & & & \\
\hline
\end{tabular}


Table 2 Relevant geometrical parameters determined through X-ray diffraction on linear P-C-P systems

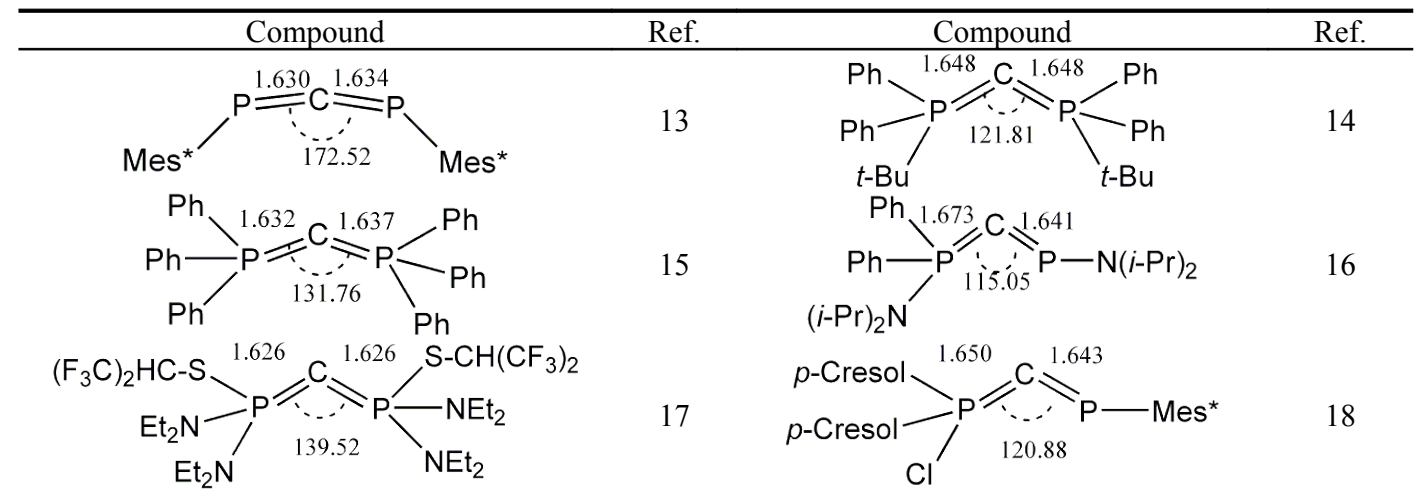


Table 3 Relative energies (in $\mathrm{kcal} \mathrm{mol}^{-1}$, compared to II.1) obtained with high-correlated methods

\begin{tabular}{l|cc}
\hline \multirow{2}{*}{ Structure } & \multicolumn{2}{|c}{ R.E.(kcal/mol) } \\
\cline { 2 - 3 } & $\begin{array}{c}\text { CCSD/ } \\
6-311++\mathrm{G}(\mathrm{d}, \mathrm{p})\end{array}$ & $\begin{array}{c}\mathrm{MP} 4(\mathrm{SDQ}) / \\
6-31++\mathrm{G}(\mathrm{d}, \mathrm{p})\end{array}$ \\
\hline I.1 & 3.70 & 3.28 \\
I.2 & 18.04 & 18.71 \\
I.3 & 23.16 & 21.88 \\
I.4 & 70.84 & 71.36 \\
I.5 & 78.15 & 85.16 \\
II.1 & 0.00 & 0.00 \\
II.2 & 8.22 & 8.40 \\
II.3 & 12.69 & 18.51 \\
II.4 & 16.16 & 16.25 \\
II.5 & 17.15 & 16.06 \\
II.6 & 22.11 & 20.47 \\
II.7 & 52.07 & 52.36 \\
II.8 & 67.61 & 70.52 \\
II.9 & 85.60 & 87.48 \\
III.1 & 30.08 & 29.15 \\
III.2 & 44.89 & 43.73 \\
III.3 & 63.46 & 63.55 \\
IV.1 & 5.04 & 3.68 \\
IV.2 & 6.84 & 5.53 \\
IV.3 & 3.89 & 3.52 \\
IV.4 & 10.77 & 9.45 \\
IV.5 & 39.08 & 37.90 \\
IV.6 & 56.36 & 55.53 \\
& &
\end{tabular}


Table 4 Wiberg bond orders for acyclic isomers of $\mathrm{CH}_{2} \mathrm{OP}_{2}$

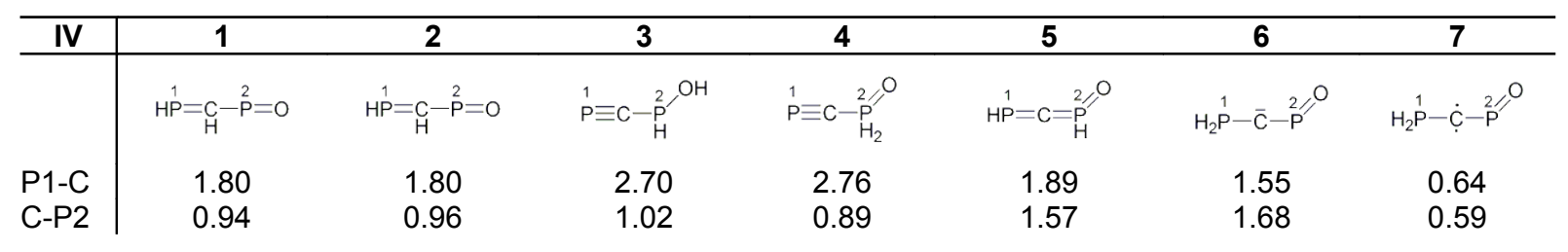




\section{Figure captions}

Fig. 1 Relative B3LYP/6-311++G(d,p) energies (in $\mathrm{kcal} \mathrm{mol}^{-1}$ ) for the investigated $\mathrm{CH}_{2} \mathrm{OP}_{2}$ isomers

Fig. 2 NB orbitals involved in second order interactions contributing to the narrowing of the P-C-P angle in IV.5: (a) lone pair on P, (b) $\sigma$ antibonding orbital on the P-C bond

Fig. 3 Mulliken charges calculated for isomer IV.5

Fig. 4 NB orbitals involved in second order interactions lowering the order of the $\lambda^{5} \sigma^{3} \mathrm{P}-\mathrm{C}$ bond: (a) lone pair on $\mathrm{O}$, (b) $\pi^{*}$ on the P-C bond 